\title{
Generalization of Water Pricing Model in Agriculture and Domestic Groundwater for Water Sustainability and Conservation
}

\author{
Tan Kim Hek ${ }^{1}$, Mohammad Fadzli Ramli ${ }^{*}$, Iryanto $^{2}$, Siti Rohana Goh ${ }^{1}$, and Mohd Faiz M. \\ Zaki $^{3}$ \\ ${ }^{1}$ Institut Matematik Kejuruteraan, Universiti Malaysia Perlis, Kampus Pauh Putra, 02600 Arau, \\ Perlis, Malaysia \\ ${ }^{2}$ Departement Matematika, Universitas Sumatera Utara, Jln. Perpustakan, No. 1, Medan, Indonesia \\ ${ }^{3}$ Pusat Pengajian Kejuruteraan Alam Sekitar, Kompleks Pengajian Jejawi, Universiti Malaysia Perlis, \\ 02600 Jejawi, Perlis, Malaysia
}

\begin{abstract}
The water requirement greatly increased due to population growth, increased agricultural areas and industrial development, thus causing high water demand. The complex problems facing by country is water pricing is not designed optimally as a staple of human needs and on the other hand also cannot guarantee the maintenance and distribution of water effectively. The cheap water pricing caused increase of water use and unmanageable water resource. Therefore, the more optimal water pricing as an effective control of water policy is needed for the sake of ensuring water resources conservation and sustainability. This paper presents the review on problems, issues and mathematical modelling of water pricing based on agriculture and domestic groundwater for water sustainability and conservation.
\end{abstract}

\section{Introduction: Intrinsic of water value for the human needs}

Access to water is a fundamental right for every person without discriminate. It makes the water is an intrinsic value that should be considered more than the value for the social, economic, religious and environmental [1].

As a fundamental right, the water needs must be fulfilling \pm 500 liters per person per day, which is essential needs for a standard living in life. The higher standard living of life, then the greater usage of water. For example, in the city of Chicago and Los Angeles each required 800 and 640 liter of water respectively. In Paris, it requires 480 liter and Tokyo requires 530 liter per person per day. Meanwhile in poor countries such as Somalia only 9 liters acquires per person per day [2-3]. Whereas in developing countries like Indonesia, in a large city requires 200-400 liters per person per day while in rural areas only 60 liter per person per day covering 30 liter for bathing, 15 liter for drink (including cooking and beverages) and 15 liter for other purposes [4].

\footnotetext{
*Corresponding author: $\underline{\text { madzli@unimap.edu.my }}$
} 
According to [5], only in 18 districts are citizens enjoyed water services out of the 35 districts in Subang district of West Java. One of the obstacles faced by rural communities is poverty thus this people have limited access to fulfill the needs of clean water that is safe and feasible. Poverty and participatory type of project is a significant factor affecting the condition of water supply system [6]. It require the help of the government or donor agencies to build water projects. Providing clean water by utilizing ground water with two bore holes each with a capacity of 5 liters/sec. Water pumped from wells drilled into the two towers of water (volume respectively 4 and $18 \mathrm{~m}^{3}$ ). From water tower, then it is supplied to houses. However, this method is ineffective because it requires a large cost.

In Surabaya, Indonesia, water problem is serious in terms of both quantity and quality. In 2025, it is predicted a deficit of water for a population of 3.04 million people and water need to reach $47.05 \mathrm{~m}^{3}$ per second while water availability is only $39.62 \mathrm{~m}^{3}$ per second. Therefore, it is water deficit of $7.43 \mathrm{~m}^{3}$ per second. This happens because water pollution is severe in Surabaya as a supplier of drinking water for the channeling of water increasing the cost of prevention and the use of chemicals treatment is high. As a result, $85 \%$ of people/households seek other alternatives to buying drinking water and household behavior bring economic consequences in the form of additional expenditure [7].

In Java Island, availability of water per capita per year is only $1750 \mathrm{~m}^{3}$, which is below water sufficiency standard of $2,000 \mathrm{~m}^{3}$ per capita per year. Conditions are expected to worsen in 2020 where availability only $1200 \mathrm{~m}^{3}$ per capita per year [8]. This is because the population is widespread and limited ability of local communities to obtain financial support in financing the investments needed to improve service facilities and infrastructures, as well as the investment of non-physical consisting of management, technical and human resource development in water management.

\section{Optimal water price reflecting sustainability}

Water occupies a very important position and strategic location in the life of the community and the nation [9]. Therefore the water should be available at a particular location and the right time and should be retrieved easily. For the protection of everyone's access to water, the water right becomes the highest priority in human rights. Therefore, the state must respect, protect and fulfill the needs for public survival. However, the government/state often ignores the rights evidenced by the many areas such in Medan is still a shortage of clean water availability and the price of water is relative expensive [10].

According to [9], in order to obtain optimal water price, it must consider the total water comes into the storage container (aquifer) and the total water that comes out because the total water affects estimates of evaprotranspiration. The amount of water that cans entry to the storage container is:

$$
I N F L O W=Q_{S W I}+Q_{G W I}+Q_{P P T}+Q_{T W}
$$

where: $Q_{S W I}=$ The flow of surface water entering aquifer

$Q_{G W I}=$ Incoming groundwater flow

$Q_{P P T}=$ Precipitation

$Q_{T W}=$ Water entering aquifer from another source.

Total water that comes out is:

$$
\text { OUTFLOW }=Q_{E T}+Q_{N D}+Q_{S W O}+Q_{G W O}
$$

where: $Q_{E T}$ : Evapotranspiration

$Q_{N D}$ : Water requirements

$Q_{\text {Swo }}$ : Surface water flow out

$Q_{G W O}$ : Ground water flow out 
In Chile, price of water is an economic policy instrument that may affect the environment, social and economic efficiency. Water scarcity has caused high water prices, causing consumers reduce water consumption and also worsen by less access to water services. The price of water is an economic policy instruments that are useful to affect the efficient use of water. A well designed water price will produce good objectives such as the promotion of economic efficiency, equity, environmental and water conservation measures in water scarce areas, public acceptance and politics [11]. The proposed water rate is based on the following idea:

$$
R_{F B}+R_{S B}=C R_{U R}+E R_{S}+E R_{W S}
$$

where $R_{F B}$ and $R_{S B}$ represent total perceived revenue from the first and second block respectively, $C R_{U R}$ is the current revenue received under the uniform rate tariff structure, ERs represents the required extra revenue to cover subsidy costs and $E R_{W S}$ is the additional revenue due to the increased tariff to signal water scarcity.

\section{Mathematical modelling of sustainability and conservation of water resources in the future}

Indeed, none of technology appropriate to prevent such degradation of water resources, even if the change in approach that offers a selection of technical, financial and institutional, but there will be changes to the environment, to the community needs to respond to the condition of the state with the prevention, protection and preservation sustainable water resources [12].

A study in [13], in Fendong District Fenhe Region, Shanxi Province, China an area of critical water resources, with irrigation efficiency water use is $65.8 \%$, industrial $(14.6 \%)$ and ecology $(6.2 \%)$. The development of water resources is slower in comparison to the development of industrialization and urbanization. These are due to rapid population growth and determine the policy mistakes of the water so that the sustainability of water needs to be concerned. The optimization model for agricultural water transfer:

Objective:

$$
\operatorname{Max} Z^{ \pm}=B A^{ \pm} B S+B T-\left(A B^{`}+B S^{`}+B T^{\prime}\right)
$$

The objective of the optimization model for agricultural water transfer is maximizing incremental benefit of water resources. The water amount transferred from agriculture to second industry and tertiary industry are chosen as decision variables.

A study by [14, 19-22] explored the behavior of water resources system imposed by climate change and population growth. They developed a dynamic model that stimulates changes in water governance through the integration process of supply, demand and asset management. Integration is a feedback loop that is used to express the relationship between the structure of rates, the level of demand and funding capacity which is designed in the modelling the scenario of various countries. This model shows an alternative rate structures to lower demand in the period of scarcity. The water demand sub-model estimates annual water demand, which is driven by three key variables: population, per capita water demand and climate impacts. These are calculated using the following equations:

$$
\begin{aligned}
& A W D=P x W D_{P C} \\
& P=\int\left(P_{c h}\right) d t+P_{i}
\end{aligned}
$$




$$
W D_{p c}=W U_{p c} x C_{i}
$$

where $A W D$ : Annual Water Demand; $P$ : population; $P_{c h}$ : population change; $P_{i}$ : initial population; $W D_{p c}$ : per capita water demand; $W U_{p c}$ : per capita water use projection; $C_{i}$ : climate impacts.

A study by [15] explains that increasing economic and population growth in developing countries led to problems of water scarcity and water pollution as the case in the area of Tian Jin, North China. The model adopted is a dynamic model that reflects the water management system which includes three sub-models: (i) socioeconomic, (ii) cycle springs, and (iii) the flow of pollutants. All three sub-models can react with each other to encourage and limit the development of each model. This model was used to analyze the potential of reclaimed water as waste water that can be recycled which is safe for a variety of uses. This study shows a good simulation of the socio-economic and environment arising from the use of reclaimed water.

The dryness caused by reduced groundwater recharge and depletion of groundwater, causing a threat to farmers in Iran [16]. The technique used in this study was engineered storage of water in the aquifer and is a technique that could minimizes the water loss due to high evaporation from dams and reduces soil depletion due to excessive exploitation of ground water that is causing a threat to drought. They developed ASR (Aquifer Storage Recovery) working to move surface water into aquifers through infiltration or injection of water in the dam then you have available can be used with conventional pumping and with the design of the dam it can reduce groundwater recharge. Model ASR profitable for farmers in these regions due to water depletion rate decreased significantly (from 14.5 meter per 40 years to 3 meters during the same period) and evaporation of the reservoir decreased by 50 million $\mathrm{m}^{3}$ during the simulation period. During periodic simulation, aquifer storage, $S_{i}$ is related to aquifer head using the relationship between storage and head in an unconfined aquifer:

$$
S_{t}=\left(h_{t}-Z_{b e d}\right) \cdot \Delta X^{2} S_{y}
$$

$S_{y}=$ the specific yield of the aquifer;

$Z_{\text {bed }}=$ the bedrock elevation (L).

A study by [17] extends that the water needed by each person depends on groundwater. The ground water is of growing importance in agricultural production, especially in the Middle East country. As the climate changes that cause global warming and low rainfall resulted in groundwater levels decreased in Hamedan-Bahar, Iran. Ground water has affected the public water suppliers in the extraction of the competition over the use thus causing more exploitation consequently causing damage to the order of the aquifer. The groundwater volume changes due to individual variables of the aquifer balance equation (such as precipitation or exploitation) the water table depth also changes according to the following equation:

$$
\Delta S_{i}=S_{t}-S_{t-1}=\Delta V \cdot \frac{1}{A \cdot q}
$$

$S_{t}$ is the water table depth (height of water pumping) in year $t ; A$ is the area of aquifer $\left(\mathrm{m}^{2}\right)$, and $q$ is the specific yield of the aquifer.

A study by [18] explained that in Medan it is frequent water shortages and interruption of water by distrbutor at certain hours. This happens because the population of Medan is large with 2,191,140 inhabitants of 502,735 households and the widespread diversification across various sectors of economic use of water for both irrigation and livestock farming. Pollution is high that approximately 2 million tons of waste every day which pollute the water, environment and catchment area increasingly destroys the water resources [1]. In 
addition, the management of the water supply is still weak for their cross-subsidy occurs between consumer usage of water (based on Regulation No. 23, 2006) that generate inequality in the consumption of water with same water quality. Therefore, it needs optimal water pricing to guarantee water sustainability. The dynamic model expressed in mathematical equation established equation of revenue, $R$ from selling water is influenced by the size prescribed rate; the rate consists of a low rate, $L R$; the basic rate, $B R$; full rate, $F R$; special rate, $S R$; and the total cost, $T C$ required for operation. The equation is proposed as follows:

$$
R=\alpha_{0}+\alpha_{1} T C+\alpha_{2} B R+\alpha_{3} L R+\alpha_{4} F R+\alpha_{5} S R+\alpha_{6} \operatorname{lag} R+\xi_{1}
$$

$R$ is called the overall demand or aggregate demand, $A D$. This revenue formed optimal water price:

$$
P=\lambda_{0}+\lambda_{1} R+\xi_{7}
$$

where;

$$
R=\left(\alpha_{0}+\alpha_{1} T C+\alpha_{2} B R+\alpha_{3} L R+\alpha_{4} F R+\alpha_{5} S R+\alpha_{6} \operatorname{lag} R+\xi_{1}\right)
$$

where $\alpha_{0}, \alpha_{1}, \alpha_{2}, \alpha_{3}, \alpha_{4}, \alpha_{5}, \alpha_{6}$ are parameter estimation and $\xi_{1}, \xi_{7}$ is disturbances/error terms. The optimal price is influenced by revenue, $R$ and the price is called the aggregate supply, $A S$. In the order for optimal water price can be achieved when $A D=A S$ (reach equilibrium).

\section{Conclusions and suggestions}

Based on research that has been done a number of conclusions as follows. Water infrastructure must be well maintained to achieve sustainability thus improve the community welfare and future generations. Determination of the optimal price of water is necessary because water prices concerns about the value of water and the actual price of good water management, proper and reality set by channeling the water to provide services for the community. Based on research that has been done and scenarios of water pricing policies, some suggestions are: water resources is the main priority of infrastructure and basic needs of the community so that the correct water management and optimal pricing can prosper public life. The traditional presume that they thought the water resources as belonging to the public and controlled by the state so that the waste water usage occurs while this is now water has become economic goods that need to be guarded and maintained as well as the investment required to maintain sustainability.

\section{References}

1. Sanim Bunasor, Sumberdaya Air Dan Kesejahteraan Publik Suatu Tinjauan Teoritis dan Kajian Praktis, 25-37 (2011)

2. Widiyanti, Ni Luh Putu Manik, Ristiati Ni Putu, Ekologi Kesehatan 3, 64 (2004)

3. Rohmania Prihatini, Kualitas Air Isi Ulang Pada Depot Air Minum Di Wilayah Kabupaten Bogor Tahun 2008-2011, Makalah Universitas Indonesia, Jakarta (2012).

4. Depkes, Peraturan Menteri Kesehatan Republik Indonesia No.492/Menkes/Per/IV/2010, Tentang Kualitas Air Minum (2010)

5. Saskya Sastavyana, Pemodelan Sistem Penyediaan Air Minum Perdesaan yang Berkelanjutan dengan Menggunakan Analytic Network Process (Studi Kasus: Kabupaten Subang), 21, 81 (2010). 
6. Masduqi Ali, Noor Endah, Eddy Soedjono, Sistem Penyediaan Air Bersih Perdesaan Berbasis Masyarakat (2008)

7. Kusumawardani Deni, Valuasi Ekonomi Air Bersih Di Surabaya (Studi Kasus Pada Air $P D A M)(2010)$

8. Maryati Sri, Keterkaitan Variabel Lingkungan Terhadap Biaya Penyediaan Air Minum, (2009)

9. Nababan Ester. S. M, Model Daya dukung Ketersediaan Air Dengan Koefisien Stabilitas (Studi Kasus pada Kawasan Industri Sei Semangkei. Kabupaten Simalungun) (2012)

10. Ediyanto, Kajian pengelolaan Air Indonesia ke Arah Pembangunan yang berkelanjutan (2009)

11. Maria Molinos-Senante, Guillermo Donoso, Utilities Policy 43, 107 (2016)

12. Pujawan, I. N., Ekonomi Teknik, $2^{\text {nd }}$ Edition (2009)

13. Dongmei Zhang, Ping Guo, Agricultural Water Management 170, 5 (2016)

14. Sahin O., Siems R. S., Stewart R. A., Michael G. Porter, Environmental Modelling \& Software 75, 348 (2016)

15. Nan Xiang, Jinghua Sha, Jingjing Yan, Feng Xu, Water 6, 17 (2014)

16. Amir Niazi, Shiv O. Prasher, Jan Adamowski, Tom Gleeson, Water 6, 2300 (2014)

17. Hamid Balali, Davide Viaggi, Water 7, 5258 (2015)

18. Tan Kim Hek, Mohammad Fadzli Ramli, Iryanto, AIP Conference Proceedings 1847, 020022 (2017)

19. Rob Dellink, Roy Brouwer, Vincent Linderhof, Karin Stone, Ecological Economics 71, 63 (2011)

20. Kostas Bithas, Antonios Kollimenakis, Georgios Maroulis, Zafeiria Stylianidou, Procedia Economics and Finance 8, 73 - 82, (2014)

21. Jaime J. Sadhwani, Jose M. Veza, Carmelo Santana, Desalination 185, 1 (2005)

22. Vašak M., Banjac G., Baotie M., Matuško J., Procedia Engineering 89, 1031 (2014) 